\title{
ENHANCING STUDENTS' MOTIVATION AND READING ACHIEVEMENT TROUGH HYPNOTEACHING METHOD IN CLASS XI STUDENTS
}

\author{
Muhammad Zainuddin \\ Sekolah Tinggi Ilmu Ekonomi Tenggarong \\ muhammadzainuddin@stietenggarong.ac.id
}

\begin{abstract}
This research aims to find out (1) the influence of using the Hypnoteaching method in improving students' motivation, (2) the influence of using the Hypnoteaching method towards students' reading achievement and (3) the influence of using the Hypnoteaching method in enhancing students' motivation and reading achievement. This is quasi-experimental research with the pre-test and post-test control group design. This research was conducted at class XI students in Madrasah Aliyah Negeri Unggul Tenggarong. The data were collected using tests and non-test. The data were analyzed by using the Multivariate Analyses of Variance (MANOVA) at the significance level of $95 \%(\mathrm{p}=0.05)$. The results of this research are as follows. There is an influence of students' learning motivation after teaching by using the Hypnoteaching method. There is a significant difference in students' reading achievement after teaching by using the Hypnoteaching method. The Hypnoteaching method affects students' achievement in reading and student's learning motivation after getting treatment, the data of Wilks'Lambda have a significance $(\mathrm{F}$-value $=6.963)$ and $\mathrm{sig}=0.02<0$.
\end{abstract}

Keywords: hypnoteaching, motivation, reading

\section{INTRODUCTION}

Education was the central aspect of improving civilization, culture, and country. The improvement of education shall improve knowledge directly or indirectly. It also holds the primary role in the development of Human Resources (HR) in a country. The teachers are a very important pillar in building human resources they hold the primary role in creating an effective teaching-learning activity. Because the teacher has direct access to interact with students in the classroom. The direct interaction and communication between the teacher and the students in the classroom will create close communication between both sides. Thus, this process creates a direct effect on the quality of education itself. A good quality of teaching also reflects the quality of the teaching-learning process between the teacher and the students. Moreover, (Tariq, et.al 2011, p.13) states that students' motivation in the classroom mostly focuses on the selfcentered goals or named as performance goals and mastery goals.

Harmer (1983, pp. 51-52) states that learning environment and interesting classes become part of the students' interest in learning. In creating good learning environment the teacher must deal with creating an appropriate environment. Besides, create an appropriate environment, the teacher might use various teaching methods and strategies that make students not bored and tired. The research was done by $(\mathrm{Xu}, 2011, \mathrm{p} .206)$ claimed that using various teaching and learning strategies increased students' motivation in learning mean $=4.53$ were moderately high degree. Furthermore, another research done by (Hasbullah \& Rahmawati, 2015, p. 88) claimed 
that the use hypnoteaching method improved students' motivation score about $18 \%$ and it categorized as high motivation showed increases of students' motivation and learning achievement when taught by using various teaching strategies and method.

Moreover, motivation aimed to improve the teaching result, several experts from numerous cross-disciplinary define the definition of the learning motivation. It is a great challenge for the present teacher to motivating students in the classroom, motivated students can see from students' attitude in the classroom, such fun in the classroom, never look sad, and all conditions can see by the teacher (Cambria \& Guthrie, 2010, p.16). Mahadi \& Jafari, (2012, p.232) tell that the students have various motivational level, so it is mean that the students might have various kind of the motivation types, (Brown, 2000, p.72-74) divides motivation into the two perspectives, a behavioristic motivation, and cognitive definition. The behavioristic motivation, this theory offers the using of giving rewards and punishment in enhancing students' motivation. Nevertheless, the students will risk their competence and ability only to gain an incentive or rewards given by the teacher, and the greater rewards offer will make the students harder to try.

The cognitive definition focuses on the students' motivation that appears from inside students-self. It has different from behaviorist motivation that focuses on giving rewards and punishment. There are three different theories illustrated self-motivation. (1) Drive theory from David Ausbel 1968 in (Brown, 2000, pp 164-166) claims that human drives can be elaborated into six drives. Exploration, manipulation, activity, stimulation, knowledge, ego enhancement. (2) Hierarchy of needs theory, Abraham Maslow's theory about the hierarchy of need is the famous theory of cognitivist motivation which he divided human pursue from the higher of pyramid until the lowest hierarchy. (3) The self-control theory focuses on the person importance of deciding on what they will do or think. Wang $(2015$, p.159) states that reading is an activity with complex psychological aspect and a process of thinking ability, added to this, (Harmer, 1983, p.199) states that reading is receptive skill where the road is receiving written in the language. Finally, (Akubuilo et al., 2015, p.38) states that reading is a lifelong skill to be used both at school and throughout life. So, reading is the process of constructing meaning through the dynamic interaction among the readers, which it used for the students in the future.

The teaching of reading (receptive skill) is different with productive skill, (Harmer, 1983, p.210) states there were two kinds of reading that can teach, they are extensive and intensive reading. The teacher should create or use an appropriate teaching material that relates to the students' age. Furthermore, (Patel \& Jain, 2008, p.119) states that material for extensive reading will be selected at a lower level of difficulty than that for intensive reading. The second is intensive reading, (Patel \& Jain, 2008, p.117) states that intensive reading provides a basis for explaining the difficulties of structure and for extending knowledge of vocabulary and idioms. It 
also provides material for developing greater control of the language in speech and writing. Added to this Yang, Dai \& Gao (2011) state that the intensive reading has dominated by the teacher-centered in the teaching English in the classroom, the students do nothing, they just read, write, listen, imitate and memorize.

Nowadays, more of teachers focus on teaching using conventional method, it utilized by the teacher because it was cheap, use in large group and students also it easy to apply by the teacher. The aim of using the conventional method for students was to preparing students to receive and remember the materials. So, it is necessary for the teacher to implement a creative teaching-learning strategy and method in the classroom. Besides that, Hypnoteaching was a teaching-learning method that was an interactive and warm teaching method. So, it built a close relationship between the teacher and students.

Hypnoteaching was different from hypnosis which it is known as how to process to make a person to sleep (Kurniawati, et al., 2014, p.131). It did not bring a person to a trance condition and subconsciously ordered by the hypnotist. Hypnoteaching here was brings to subconscious learning states from the students' brain waves from beta to alpha condition. The teacher must be able to make pleasant and enjoyable learning environment to increase students' unconscious mind. The process of teaching learning ability not just focus on how to make students able to get his or her subconscious mind, it also how to create a pleasant situation because with creating a delicate situation. Furthermore, (Yustisia, 2012, pp.77-75) states that hypnoteaching is a teaching activity that involves students subconscious mind. It means that the students in the classroom must be aware of their subconscious mind. It means that hypnoteaching is different from hypnosis. The person's mind is an unlimited area with a broad range of possibilities that are unpredictable. Furthermore, (Hakim, 2010, pp.1-2), states that hypnosis is a state of the human of mind when the sujet ( the person who get into trance condition) reduce their reaction in the logical analysis of their mind and allow the hypnotist to get into their sub-conscious mind. So, the hypnoteaching is a method that involves the students' alpha wave condition. There were several steps in conducting a hypnoteaching method. According to (Hakim, 2010, pp.28-29) states, there were several steps in using Hypnoteaching as a teaching method such; intention and motivation, pacing, leading, using the positive word, giving reward and punishment, modeling, mastered the material. In another hand, (Yustisia, 2012, pp. 85.88) states there were seven elements in the process of using Hypnoteaching such as intention and motivation, pacing, leading, using the positive word, giving reward and punishment and master the material. So, Hypnoteaching is a teaching method which it allows the teacher to be a leader in the classroom and guiding students onto the effective teaching-learning activity. 
So, based on the statements above, it is necessary to conduct a research about the using of Hypnoteaching method towards students' motivation and reading achievement at eleventh class students, the result of this research can be us as a reference in using various teaching and method in learning to enhance students' motivation and reading. The purposes of this research can be formulated as follows. (1) To investigate the difference in the students' motivational level after applying the hypnoteaching method in the teaching English. (2) To investigate the difference in the students' reading achievement after applying the hypnoteaching method in the teaching English. (3) To investigate the difference in learning motivation level and reading achievement between students who are taught by using the hypnoteaching method and those who are taught without using the hypnoteaching method.

\section{METHOD}

This research was quasi-experimental design with quantitative research approach. In this research, the researcher has chosen two class; the experimental and control class. The control class receives the same material as the experimental class; however, the treatment is only given to the experimental class. There were several steps followed by the researcher, the first step was choosing one group which does not have differences in each group. The second try-out test was given to groups to knowing the level of subject condition. The third treatment was given to the experimental group, a treatment used by the researcher was Hypnoteaching teaching method for the experimental group and in another hand, the conventional teaching method given by the researcher to the control group, post-test given to the experimental and control group and then the researcher compared the result of it.

This research was conducted at Madrasah Aliyah Negeri Tenggarong. Population in this research is all of the students in the eleventh class in MAN Tenggarong consist of 6 classes and total of students is 161 . In this research cluster random sampling used as a sampling technique, this technique determines sample from populations that equal or same. The sample was class XI Agama 1 as the experimental class and XI IPA 2 as the control class. The procedures research can be defined as follows. (1) Determine experimental group (E) and control group (C) from existing class. (2) Pre-test and post-test were given to the experimental group and control group. (3) Provide treatment to the experimental group and control group, the experimental group using Hypnoteaching method and control group using conventional teaching method. (4) Measure the result of post-test from experimental and control group using Multivariate Analysis of Variance (MANOVA). This research has two kinds of instruments for collecting data; the first is reading test, the reading test was multiple choice tests based on the students' reading material in eleventh class, it used to measure students' reading achievement. Meanwhile, the questionnaire 
used to collect data on students' motivation, the questionnaire given to the control and experimental group for twice and this questionnaire consists of 50 statement.

In collecting data, the researcher used the test of reading written test with multiple choices, and there were 45 items of reading test with five options. Besides that, the questionnaire technique used to collect data to measure students' motivation. The questionnaires were given to the students in experimental and control group before giving treatment (pre-test) and after treatment (post-test). From result obtained then compared to know students' motivation toward method provided.

The descriptive statistic used as data analysis technique in this research and the researcher also used Statistical Package for the Social Sciences (SPSS). It was to measure data collected from the test and questionnaire that consist of normality test, homogeneity test and Multivariate Analysis of Variance (Manova). Based on the empirical validity, it can be concluded that there were five questions from 50 questions from the reading test were invalid and not included in pre-test and post-test. The students' item difficulty index shown that was nineteen students $(55.8 \%)$ categorized as a higher class group, and it was fifteen students (44.12\%) categorized as a lower class group.

The validity of the questionnaire was judge by the expert judgment, and this questionnaire also uses Likert's scale from $1-5$, after that test instrument given to the students in other class which were not the experimental neither control class. From 50 items of the reading test, there were no items that invalid from the motivation instrument. The result of instrument try-out found that the test of students reading score was 0.946 which it was a very high reliable category and the reliable coefficient of motivation instrument was 0.957 which it was very high reliable. So, the researcher concluded that the reading and motivation instruments were reliable with the very high reliable category.

\section{FINDING AND DISCUSSION}

Empirical description of reading achievement and motivation obtained from the test and questionnaire that can be seen from reading score and motivation level, very high and very low score from students. The score categorized into five categories (very good, good, fair, poor, and very poor). Moreover, students' motivation measured from students' answer in the questionnaire and the score and questions divided into five kinds of motivation categories (very high, high, fair, low, and very low). Based on the table of comparison below, it shown that mean of pre-test and post-test of reading test in the experimental class increases from 52.9688 to 59.9375 , it increased 6.9687 points. It was clear that the mean of students' reading score improved from Fair to Good category after treated by using Hypnoteaching method. 
Table 1. Comparison of pre-test and post-test of reading test in the experimental class

\begin{tabular}{|c|l|c|c|}
\hline \multirow{2}{*}{ No } & \multirow{2}{*}{ Data } & \multicolumn{2}{c|}{ Reading achievement } \\
\cline { 3 - 4 } & & Pre-test & Post-test \\
\hline 1 & Maximum & 76 & 73 \\
\hline 2 & Minimum & 40 & 44 \\
\hline 3 & Mean & 52.9688 & 59.9375 \\
\hline 4 & Median & 51.000 & 61.000 \\
\hline 5 & Mode & 51 & 56 \\
\hline 6 & Standard Deviation & 9.02857 & 7.0799 \\
\hline
\end{tabular}

The table 2 below shows that the mean score of pre-test and post-test reading score in the control class increases from 51.7353 to 56.0294 or increases 4.2941 points and the standard deviation also increases. It is clear that the mean of reading comprehension achievement score of students of the control group did not improve. They still had a fair category.

Table 2. Comparison of pre-test and post-test of the control class

\begin{tabular}{|c|l|c|c|}
\hline \multirow{2}{*}{ No } & \multirow{2}{*}{ Data } & \multicolumn{2}{c|}{ Reading achievement } \\
\cline { 3 - 4 } & & Pre-test & Post-test \\
\hline 1 & Maximum & 69 & 71 \\
\hline 2 & Minimum & 33 & 44 \\
\hline 3 & Mean & 51.7353 & 56.0294 \\
\hline 4 & Median & 52.000 & 56.000 \\
\hline 5 & Mode & 47 & 56.00 \\
\hline 6 & Standard Deviation & 8.01630 & 6.88646 \\
\hline
\end{tabular}

The table 3 below shown that mean of pre-test and post-test of motivation in the experimental class increases from 159.62 to 189.09 , it increased 29.47 points. It was clear that the mean of students' motivation scores improved from Average to High category after treated by using Hypnoteaching method. 
Table 3. Comparison of pre-test and post-test motivation in experimental class

\begin{tabular}{|c|l|c|c|}
\hline \multirow{2}{*}{ No } & \multirow{2}{*}{ Data } & \multicolumn{2}{c|}{ Reading achievement } \\
\cline { 3 - 4 } & & Pre-test & Post-test \\
\hline 1 & Maximum & 189 & 231 \\
\hline 2 & Minimum & 115 & 155 \\
\hline 3 & Mean & 159.62 & 189.09 \\
\hline 4 & Median & 163.50 & 188.00 \\
\hline 5 & Mode & 145 & 187 \\
\hline 6 & Standard Deviation & 18.816 & 19.420 \\
\hline
\end{tabular}

The table 4 below shown that mean of pre-test and post-test of motivation in the experimental class increases from 165.88 to 177.79 , it increased 11.91 points. It was clear that the mean of students' motivation scores improved from Average to High category after treated by using Hypnoteaching method.

Table 4. Comparison of pre-test and post-test motivation in control class

\begin{tabular}{|c|l|c|c|}
\hline \multirow{2}{*}{ No } & \multirow{2}{*}{ Data } & \multicolumn{2}{c|}{ Motivation score } \\
\cline { 3 - 4 } & & Pre-test & Post-test \\
\hline 1 & Maximum & 200 & 215 \\
\hline 2 & Minimum & 120 & 147 \\
\hline 3 & Mean & 165.88 & 177.79 \\
\hline 4 & Median & 168.50 & 179.50 \\
\hline 5 & Mode & 182 & 182 \\
\hline 6 & Standard Deviation & 19.663 & 15.181 \\
\hline
\end{tabular}

The test of normality in this research was used Kolmogorov-Smirnov (K-S). Based on the statistics, it can be concluded that the significance of probability $(p)$ of students' motivation score in pre-test for the control and the experimental class was .862 and .241. Students' motivation score in post-test for control and the experimental class was .658 and .815; it was higher than $\alpha=0.05$ means that data of students' motivation is Normal. $(p)$ The value of students' reading score in pre-test for control and the experimental class was .611 and .478 . Students' reading score in post-test for control and the experimental class was .718 and .481. It was Higher than $\alpha=0.05$ means that data of students reading score is Normal. This research uses Levene's test and the analyzed by program SPSS statistic computer 16. In the output of the 
homogeneity test is significantly in level: 0.05 , if it Levene's test is $(p>0.05)$, it means that there is homogeneity. The result shown that the significance of probability $(p)$ of students' motivation score in pre-test and post-test was .958 and .214 and it was higher than $\alpha=0.05$ means that data of students' motivation is Homogenous and $(p)$ of students' reading score in pretest and post-test was .537 and .657 it was higher than $\alpha=0.05$ shows data of reading score is Homogeneous. So, there are no differences in theoretical distribution and empirical's distribution, and it can be concluded that the apportionment of both variables is normal.

According to the data analyzed by using SPSS 16, The result of hypothesis 1 test shows that the Significance values of students' motivation based on the Manova test were .009, it was lower that $\alpha=0.05$, and the F-value is 7.248. In this cause, Ha was accepted. It means that there is a significant difference in students' learning motivation after taught by using hypnoteaching method. The determinant coefficient (R Square) is 0.088 .

The result of hypothesis 2 test shows that the Significance values of students' reading achievement based on the Manova test were .022 , it was higher than $\alpha=0.05$, and the F-value is 5.484. It means that there is a significant difference in the students' reading achievement after taught by using hypnoteaching method.

The result of hypothesis 3 shows that the data of Wilks'Lambda had a significance (Fvalue $=6.963)$ and sig $=0.02<0.05$. It means that hypnoteaching method can affect students' achievement in reading and student's learning motivation after getting treatment. In another hand, the used of hypnoteaching method in the teaching English can enhance the students' learning motivation and reading achievement in the class who are taught by using hypnoteaching method.

According to data statistics of students' motivation, there was a significant increase in the students' motivation before and after treated by using the Hypnoteaching method. In the experimental class, there were three (9.4\%) students claimed low motivation, there were sixteen (50\%) students claimed average motivation and there were thirteen (40.6\%) students claimed high motivation before treated by Hypnoteaching method, those score significant raising after treated by using hypnoteaching method. There were 8 (25\%) students who claim very high motivation, there were nineteen (59.4\%) students claimed high motivation and there were five (15.6) students claimed average motivation. The result of hypothesis test shows that Significance values of students' motivation based on the Manova test were.009, it was lower that $\alpha=0.05$ means that there is an influence of using the Hypnoteaching method in the experimental group toward students' motivation. The using of Hypnoteaching method in the experimental class gives some advantages for students in the experimental class, students in the experimental class being a role model of a new method that can not apply by some teacher. 
Data statistics of students' reading score in the experimental class show significant is increasing after treatment by using hypnoteaching method. There were 32 students in the experimental class, in pre-test of reading there were nine $(28.1 \%)$ students who claim Good score in reading test, there were eighteen (56.3\%) students who claim Fair score level and there were five (15.6\%) students who claim Low score in reading. After treated by using hypnoteaching method, students who claim Good score level in reading test increased significantly, there were eighteen (56.2\%) students and there were fourteen (43.8\%). There was a significant influence of the using hypnoteaching method towards students' reading achievement, it can be seen in hypothesis test Significance values of students' motivation based on the Manova test was .022 , it was lower than $\alpha=0.05$ means that hypnoteaching method has influences towards students' reading achievement.

Hence, the using of hypnoteaching method increases students' reading achievement and learning motivation. It can be seen from the pre-test and post-test of the experimental class, before students treated by using hypnoteaching method the students' reading score were Fair category. Then, the researcher treated by using hypnoteaching method, it improved into the Good category.

\section{CONCLUSION}

Based on research data description above, it can be concluded as follows: (a) Hypnoteaching method influencing towards students' motivation in class XI students at MAN Unggul Tenggarong with effective contribution percentages, there were $8(25 \%)$ students who claim very high motivation motivation, there were nineteen $(59.4 \%)$ students who claim high motivation and there were five (15.6) students who claim average motivation and significances of values 0.009 lower then $\propto(0.05)$. (b) Hypnoteaching method influencing towards students' reading achievement in class XI students at MAN Unggul Tenggarong with effective contribution percentages there were there were eighteen (56.2\%) students categorized as good score and there were fourteen (43.8\%) categorized as Fair score, significances of values 0.009 lower then $\propto(0.05)$. (c) The result of pre-test in motivation and reading score for control class shows that students were claims High motivation in motivation test but most students claim Fair in reading the score, even after seven meetings result of students' post-test does not the better result. It opposite with students in the experimental class who are taught by using hypnoteaching method. There were increases in students' motivation and reading score. According to the Multivariate Test, Significances Values (p) was .002 and it was lower than $\alpha=$ 0.05 means that there was differences between group students who are taught by using Hypnoteaching method and who are not taught by using Hypnoteaching method. 


\section{REFERENCES}

Akubuilo, F. et al. (2015). Reading readiness deficiency in children: causes and ways of improvement. Journal of Education and Practice.

Brown, H. D. (2000). Teaching by principles an interactive approach to language pedagogy (second edition). California: Longman.

Brown, H. D. (2000). Principle of language learning and teaching (fourth edition). New York: Pearson Education.

Cambria. J., \& Guthrie, T. (2010). Motivating and engaging students in reading. The NERA Journal, Volume 46 (1), 16-29.

Hakim, A. (2010). Hypnosis in teaching. Jakarta: Visi Media.

Harmer, J. (1983). The practice of teaching english . Cambridge: Pearson Longman.

Hasbullah, \& Erawati, E. Y. (2015) Pengaruh penggunaan metode hypnoteaching terhadap motivasi belajar mahasiswa di universitas indraprasta pgri. Jurnal Formatif 5(1): 8390.

Kurniawati, L. et.al. (2014). Enhancing students' mathematical intuitive-reflective thinking ability through problem-based learning with hypnoteaching method. Journal of Education and Practice, ISSN 2222-1735 (Paper) ISSN 2222-288X (Online), Vol.5, No.36, 2014, 1-7.

Mahadi, T. S, . \& Jafari, T. M. S (2012). Motivation, its types, and its impacts on language learning. International Journal of Business and Social Science.

Patel, M. F. \& Jain, P. M. (2008). English language teaching (methods, tools \& techniques). Jaipur: Sunrise publishers \& distributors.

Sovodlka, P. (2010). Secret of Hypnotherapy. Jogjakarta: Flashbooks.

Tariq, S. et.al (2011). Relationship between intrinsic motivation and goal orientation among college students in pakistani context. Journal of Education and Practice, Vol 2, No 10, $2011,11-17$.

Wang, X. (2015). Effect of metacognitive strategy training on chinese EFL learners' reading competence. International Journal of English Linguistics.

$\mathrm{Xu}, \mathrm{X}$ (2011). The relationship between language learning motivation and the choice of language learning strategies among Chinese graduates. International Journal of English Linguistics, I(2), 203 - 212.

Yang, W., Dai, W., \& Gao, L. (2011). Intensive reading and necessity to integrate learning strategies instruction. English Language and Literature Studies. E- ISSN 1925-4776.

Yustisia, N. (2012). Hypnoteaching Seni mengeksplorasi otak peserta didik. Jakarta: Gramedia. 